\title{
Funny as hell: The functions of humour during and after genocide
}

\author{
Uğur Ümit Üngör
}

Department of History (Utrecht), NIOD: Netherlands Institute for War, Holocaust, and Genocide Studies (Amsterdam)

u.ungor@uu.nl

\section{Valerie Amandine Verkerke}

Department of History, University of Amsterdam

valerieverkerke@gmail.com

\begin{abstract}
The history of genocide is replete with various humorous treatments by different actors with distinctive objectives. This type of dark humour treats the topic, which is usually enveloped with solemnity, in a satirical manner. This essay aims to study the functions of humour by comparatively examining victimized individuals' and groups' use of humour during and after violent episodes such as genocide. Why do victims use humour under conditions of extreme peril, threats to life, and fear? It draws on published and unpublished memoirs, pamphlets, video clips, and most importantly victims' artistic and literary responses to the Nazi repression and the mass violence in Bosnia (1992-1995) and Syria (2011-2013). The essay argues that dark humour seems to be widespread among victims and survivors, as it functions as a complex mechanism for coping with anxiety and fear, group cohesion and critique of perpetrators. Our conclusions suggest that victimological approaches in genocide studies can benefit considerably from focusing on oppressed groups' humoristic responses to mass violence.
\end{abstract}

Keywords: genocide, Holocaust, Bosnia, Syria, functions of humour.

\section{Introduction: genocide and humour}

Genocide can be defined as a complex process of systematic persecution and annihilation of a group of people by a government. In the twentieth century, approximately 40 to 60 million defenceless people have become victims of deliberate genocidal policies. The twenty-first 
century has not begun much better, with genocidal episodes flaring up in Darfur, the Democratic Republic of the Congo, Myanmar, and Syria. Genocide is the persecution and destruction of human beings on the basis of their presumed or imputed membership in a group, rather than on their individual properties or participation in certain acts. Regardless of the type of groups that are being targeted - ethnic, religious, regional, political, sexual - a genocidal process always concerns a society at large and often destroys a significant, or even critical part of the affected communities. Genocidal processes are particularly malicious and destructive because they are directed against all members of a group, mostly innocent and defenceless people who are persecuted and killed regardless of their behaviour. For this reason, it is a phenomenon that is distinct from other forms of mass violence such as war, civil war, or terrorism (Alvarez 2010; Gerlach 2010; Bloxham \& Moses 2010).

The relationships between genocide and culture are complex and run in both directions of influence. Just as cultures can influence the course and shape of a genocide, so too a genocide can fundamentally shape the culture of both perpetrator and victim communities, and beyond. Culture, if seen in the broadest sense to include artists, writers, and intellectuals in general as well as popular mentalities, can affect the onset as well as the form of a genocide. Cultural expressions can contribute to a moral environment in which the mass killing of enemy groups, combatants and civilians alike, becomes more widely accepted. For example, before and during the First World War, most Futurists in Italy adhered to nationalism and glorified a future order established through violence (Kramer 2007: 167-169). In a similar vein, the cultural orientations in a society to a certain extent prescribe how violence is committed and against whom. As Wolfgang Sofsky has argued: "Violence is itself a product of human culture... From time immemorial people have enjoyed destroying and murdering as if it were a matter of course. Their culture assists them to give form and shape to this potency." (Sofsky 2005: 225-226) For example, cultures that are based on strict codes of patriarchal honour can spark strongly gendered violence in genocidal episodes, resulting often in massacre of men and rape of women.

The opposite influence is also common: genocides always shape cultures too. They are such powerful forces, they affect the cultures of the victim and perpetrator groups for many generations. The legacies of genocides range from bearing witness through testimony (including silences), articulating national identities, and shaping the historical imagination. Cultural responses to genocide range from literature to memoir, dance, film, poetry, music, visual arts, graffiti, and other forms of art (Lorey \& Beezley 2002). Cultural systems of particular societies absorb an enormous event such as genocide within the terms of their particular national culture. For example, the Holocaust has been a common subject in a substantial body of literature and art in many languages, but cultural responses to it differed significantly in Israel, the Soviet Union, Poland, Germany, and the United States, due to the different issues and preoccupations of those cultures before, during, and after World War II (Spargo \& Ehrenreich 2000). Much of the artwork about the Holocaust deals with the survivors' experiences in the ghettos, life in the Nazi camps, as well as liberation and post-war migration. All of these literary expressions attempt to make sense of the great catastrophe, and some of this work is even humorous, such as the semiautobiographical fiction of Isaac Bashevis Singer and Edgar Hilsenrath (Roskies \& Diamant 2012).

Much as the violence of genocide is different from that of war, the specific characteristics of humour during genocide is also different. One main distinction is that during war, there is suffering but no impending extinction, and those on the receiving end of violence still have broad access to public culture, including humorous forms. For example, both world wars saw the 
proliferation in Germany and France of 'war comedies', theatre plays that addressed various aspects of the nation's experience with the respective war (Mosse 1990: 144-147). Conversely, during genocides, humour collapses in options as the victim group's access to the public sphere shrinks drastically. Another main difference is that genocide assaults the very existential foundations of the victim group, including its collective identity and its culture. Genocide reformulates the relationship between the perpetrator group and the victim group, possibly forever: this acute constellation of superiority and inferiority, aggrandizement and disempowerment, sparks forms of humour that react to this new social reality. From the academic discipline of victimology we can distill three main types of responses to victimization: fright, flight, and fight (Jones 2007: 80). Humour can relate to all of these, including resistance (see below). Since the victim group is continuously dehumanized, it must persistently rehumanise itself, by maintaining a modicum of normalcy, and often through cultural activities including humour. How does mass violence produce humour? And how do victims respond to victimization through humour?

This article explores how genocide, in particular mass victimization, produced humour in three cases: the Nazi mass murder of Jews during World War II, the Serbian genocide against Bosnian Muslims (Bosniaks) during the Yugoslav civil wars, and the Assad regime's massively deadly violence against the Syrian opposition from March 2011 on - recognized as genocidal by academic experts, the United Nations, the United States Holocaust Memorial Museum (UN 2013; USHMM 2013). Besides the obvious differences between these conflicts, in terms of genesis, scale, space, and time, there are some crucial similarities that merit comparative analysis. In all three cases, mass victimization resulting from violence against civilians destroyed and disrupted the lives and social ties of the victim groups, Jews, Bosniaks, and Syrians. In all cases, the victims suffered not only non-lethal forms of violence, such as torture, siege, expulsion, and expropriation, but they faced wholesale massacre of their group, which assaulted the foundations of their group. In all cases, there was a prehistory of a distinct, characteristic, self-deprecating sarcastic humour. All three victim groups are minorities that have a long tradition of being governed and often persecuted by foreign powers. This disempowerment in the asymmetrical relationship between minority and majority has come to be expressed in their popular cultures through humour. And in all three cases, there is abundant evidence of humorous responses to the relevant episode of genocide. For the sake of consistency and delimiting the article's scope, we exclude humorous responses by the perpetrators and focus on the victims only. What types of humorous responses to victimization appear in these cases? We examine the functions of these forms of humour, not only during, but also after the victimization, since we found evidence that humour persisted well after the violence ended. We approach these questions through a critical analysis of a broad source base: memoirs, oral history interviews, published jokes, stand-up comedy shows, YouTube clips, blogs, documentaries, newspaper articles, and secondary studies.

This article also engages with theoretical discussions in humour studies. The three classical humour theories still form a foundation for much humour research, although no theory on its own is comprehensive enough to explain all cases of laughter. In a nutshell, "incongruity theory looks at the structure of humour, the relief theory at the effects of humour and the superiority theory at the feeling the joke appeals to" (Kuipers 2001: 23). According to the classical relief theory, humour functions mainly as a release of tension. Laughter is a physical outburst that creates a relaxed and liberated feeling because it releases endorphins, basically a natural painkiller (Kuipers 2001: 31). A study by Herbert Lefcourt (2001) concluded that individuals 
with a greater sense of humour are thought to be more capable to cope with stress, to get along well with others, and to enjoy better mental and even physical health. Laughter could also function as a relief of social tension or repression (Kuipers 2001: 34). In cases of genocide, humour could function as a physical relief but also of a social relief, since it affects the balance of power. The incongruity theory argues that humour is based on the perception of incongruity. A joke is funny when there is a discrepancy with what is expected and what is actually happening. These incongruities could be jokes with a double meaning or jokes in which social roles are turned upside down (Kuipers 2001: 23). Incongruity appears a lot in examples of jokes by victims of genocide, since their reality suddenly became very different from the world they expected to live in. The oldest theory is the superiority theory, dating back to Plato, arguing that humour is always based on power and aggression (Kuipers 2001: 28). Ted Cohen turns this around by saying humour is also a response of the weak to their suppressor (Cohen 2001: 380). Much like the relief theory, it could keep the power balance in check because victims of genocide are placed in the minority role of the powerless victims. Jokes could function as a way to cope with this new role and with their powerful opponent.

Keeping these theories in mind, this article will focus on three prominent approaches to genocide humour, in order of salience: coping, cohesion, and criticism (Morreall 2001; Thurston 1991; Tsakona \& Popa 2011). A primary function of genocide humour is coping. It can be seen as an emotional mechanism: a reduction of, or an escape from pain. This approach suggests that laughing in the face of victimization does not trivialize genocide, but dispels it: the laugher distances himself of sorrow and fear. The energy produced that is discharged is the emotional energy that otherwise would have been devoted to the negative feelings of pain and sorrow. Coping through humour seems to play a role during genocides as victims attempt to cope with their condition by using different forms of humour with different meanings and contexts. A second function is cohesion: dark humour about victimization is seen as a form of cognitive and emotional bonding between groups of perpetrators, victims, and bystanders. This kind of humour is not accessible to outsiders because they are meant to form boundaries, distinguish groups, and in some cases exclude and denigrate the Other. Many jokes will be highly context-sensitive, i.e. conditional: they will only work on condition that the audience has both the knowledge and information processing ability required to understand them. If the conditionality level is very high, these in-group jokes are hermetic, and deeply embedded in the group's culture. A final function of humour in genocide is often seen as criticism: when one person tells a joke and another listens to it, this micro-interaction produces protest culture against the oppressor. In other words, by containing a clear target, victim humour was a form of criticism and resistance against the oppressing group or regime. This cognitive theory, rather than focusing on the emotions of the actors, emphasizes the intellectual aspects of humour. Laughter is viewed as the outcome of creative problem solving, an activity that requires some degree of information processing or the mental manipulation of symbolically represented persons or concepts. We list these three functions in order of political salience: arguably all humour enables some measure of coping, some humour also builds a sense of cohesion or solidarity since it draws upon shared experiences and even intimacy (Cohen 1999: 10), and finally, humour that is critical can be interpreted as most activist and political. 


\section{The functions of humour for Holocaust victims}

Jewish humour has a tradition of being distinctively self-mocking and self-derogatory. Historically, European Jews have come to tell and invent jokes about members of their own community and assign negative, stereotypical qualities to them. Jewish jokes have continuously played with the hostility towards their people and anti-Semitic stereotypes (Ziv \& Zajdman 1993). Even during the Holocaust laughter and joking was widespread among the Jewish victims in the Nazi concentration camps. (A distinction has to be made between concentration camps and death camps: Jews who were taken to death camps such as Treblinka or Sobibor, were almost always taken to the gas chambers directly upon arrival.) Most examples of jokes come from survivors of concentration camps, who were able to survive because they managed to become indispensable in the camp economy. Although the largest percentage of Jews died in AuschwitzBirkenau, it was a forced labour camp as well. Jewish humour in Nazi concentration camps consists mostly of oral jokes since there was hardly any access to a public sphere. These jokes survived along with their tellers or listeners and were collected by Steve Lipman and Rudolph Herzog, among others (Lipman 1993; Herzog 2012).

Humour functioned as a coping mechanism for victims and survivors of the Holocaust. For example, laughter could function, even in the most horrible circumstances, as a short moment of relief, in which the victim could distance himself from any negative feelings. Holocaust survivor Leontine Tels-de Jong talks in an interview about the terrible situation she found herself in during the transport from the Dutch transition camp Westerbork to Theresienstadt. Too many people were crammed into one carriage without sufficient water, food, and toilet facilities. Amidst this horrible story, Tels-de Jong suddenly starts laughing. She explains that during the journey the train stopped a lot at stations to wait for signals. When the train stopped yet another time a man next to her said: "Ladies and gentlemen, when the train stops again, let's pretend this train is full already!" According to Tels-de Jong, the whole carriage started laughing. (Tels-de Jong.) In a moment of great stress, the tension was broken, if only for a short amount of time by cracking a joke about the absurdity of their situation. The joke combines normalcy with the absurd conditions the victims found themselves in.

This absurdity is crucial when looking at humour as a coping mechanism. People normally function on the basis of specific assumptions about life that allows them to set goals, plan activities, and order their behaviour. These assumptions do not prepare them at all for extreme events. In cases of war, violence, and genocide, all familiar goals in life are snatched away (Janoff-Bulman 1985: 15-17). Humour can be a powerful tool to cope with this, as the incongruity between the old, familiar life and the new, brutal reality has never been greater. According to Holocaust survivor Viktor Frankl, "An abnormal reaction to an abnormal situation is normal behavior" (Frankl 1992: 4). Lipman describes humour as a mad reaction to preserve or restore sanity, because the thought that human beings intentionally organized at Auschwitz was unbearable (Lipman 1993: 14).

Laughter can offer a brief escape from reality and one could distance himself from negative feelings such as fear and grief. However, before removing themselves psychologically from the horrors, victims had to face and adapt to the new reality. Adapting meant survival, and resistance, either physical or mental, would lead nowhere. In the Nazi concentration camps, the only long-term survivors were those who managed to become indispensable for the camp economy. These victims endured oppression, violence, and death for a prolonged period of time, and for some, dark humour functioned as a coping mechanism. Frankl describes how prisoners 
were first taken by a feeling of shock. This initial phase of surprise was then replaced by a phase of apathy, in which the prisoner achieved some kind of emotional death, seeing so many people die around them. However, there was still a sense of humour to be found. According to Viktor Frankl, in grave circumstances, "what alone remains is the last of human freedoms; the ability to choose one's attitude in a given set of circumstances" (Frankl 1992: 4).

Janny Moffie, a Dutch Jew who survived Auschwitz, said in an interview that she used to make a lot of jokes to keep her mind off the camp's grim reality. For example, she had to hack into frozen ground, which was really brutal work. She said to the woman next to her for encouragement: "Come on, this is exactly the kind of work I trained for, so 1-2-3!" She actually mocks her own victim-role by pretending she was actually trained to do this in her life before the war. She also tried to talk about a book or a favourite recipe, just to stay strong mentally. (Moffie.) By joking about the circumstances, she kept her inner strength, just as Frankl stressed. The Dutch Holocaust survivor and prolific memoirist Elie Cohen also described the struggle for survival in the concentration camps. He recalled that only those prisoners who had adapted to the new circumstances could laugh. They were not only preoccupied with the question why this had happened to them, but they tried to function with some degree of normalcy. Humour functioned as an escape from the morbid reality, but at the same time people were also very indifferent and joked as if normal life still existed (Cohen 1959: 151).

Besides coping, jokes are also highly social phenomena that can establish and strengthen social relationships. Making someone laugh is key to consolidating relationships (Ziv 2010: 12). Several sociological studies focus on humour within a social setting, such as hospitals, prisons or office environments, as well as the social functions humour has in specific situations and relationships. The jokes people tell each other in their own specific social setting could be misunderstood or interpreted as offensive by outsiders. This creates a common language and a sense of uniqueness for the in-group, because their insider jokes bear no meaning to outsiders (Ziv 2010: 14). For example, doctors joke about their patients, not to make fun of them, but to cope with their difficult jobs, in which death and disease is omnipresent. Another study involved the tradition of storytelling and joking among American paramedics, which is steeped in strong language, gruesome details, and laughter - entirely inaccessible and incomprehensible to outsiders. It enables the group to assert some sort of control over uncontrollable events (Tangerlini 2000: 46). This dark and sarcastic kind of humour could be deeply offensive to patients and their families. Context is everything and a joke among residents in a hospital would be totally inappropriate in a different social environment. Whether a joke is considered funny or not depends on the positionality of the joker and his/her audience. When humour is directed at the in-group, it can enhance bonds, establish trust, and maintain intimacy. It can generate a sense of group identity and security.

Bearing this in mind, it is no new finding that in times of conflict and genocide, humour can forge bonds among victims. The escalating Nazi persecution of various political and ethnic categories in the 1930s in itself drove the regime's opponents together, and cabaret flourished, first in Germany, and later in the ghettos (Rapaport 2006: 252-269). According to John Morreall (2001), anti-Nazi humour produced solidarity among the Jewish victims during Nazi rule. However, self-ridicule could strengthen the bond between Jews as well. Keltner and Bonnano claim that "intrapersonal and interpersonal benefits of laughter are widely believed to contribute to improved psychological functioning during periods of stress", because laughter is contagious and increases the cohesion of groups (Keltner \& Bonnano 1997: 688). Many survivors mention that it was necessary to bond with other prisoners in order to survive, and humour was an 
effective way to bond with fellow inmates. Elie Cohen, when describing concentration camp behaviour, noted that comradeship in the camp was vital, and lone wolves did not survive long. According to Cohen, humour was one form of sharing that facilitated comradeship (Cohen 1959: 104). Anna Pawelczynska also sees cohesion as a survival mechanism and humour is a way to be accepted by a group of fellow prisoners: "The collective strengths of a group give support to the prisoner. To be accepted by a group of fellow prisoners, one needed certain traits of character that eased the process of living together: friendliness, readiness to help, patience, tolerance, selfcontrol, quick reflexes and a sense of humour" (Pawelczynska 1979: 130).

Finally, criticism became increasingly widespread among Jews subjected to the ever escalating Nazi persecution. During World War II, humour existed in the Nazi concentration camps, but the question remains whether this type of humour produced belligerence or fatalism and inactivity (Lipman 1993: 11). Contrary to common knowledge, the Nazis allowed and even encouraged some form of humour in the camps. For example, the Dutch transit camp Westerbork even had a camp theatre for the Jewish inmates. According to Holocaust survivor Viktor Frankl, cabaret was used as distraction, to keep the prisoners from revolting (Frankl 1992). It could also have functioned for the entertainment of the camp leaders. However, among Jewish prisoners jokes circulated that were critical of the Germans and prominent Jews: "The sight of a raging SS officer became less menacing as soon as one imagined him with his pants down or lying drunk in the mud" (Pawelczynska 1979: 129). Antonin Obrdlik even claimed that anti-Nazi jokes in Czechoslovakia during the Second World War were a form of resistance because they were an expression of aggression and resistance against the oppressor (Obrdlik 1942). The victims used humour to render the oppressor less frightening, but it also aimed at ridiculing the role of the victims themselves. For example, the following joke set in Auschwitz provides a sarcastic critique of the Jews' alleged fatalistic attitude:

Two Jews are about to enter the gas chamber in Auschwitz. One of them turns to the SS guard to make a last request for a glass of water. 'Shah, Moshe', says his friend.

'Do not make trouble'.

(Lipman 1993: 193.)

The joke involves a gas chamber, but it is a joke that is much more about Jewish traits and not so much about the Holocaust. Taken at face value, this joke mocks the fatalism of the Jews, always accommodating and conforming instead of rebelling, even when facing death. However, by ridiculing themselves, the victims also undermine the power of the perpetrator - arguably the key element of Jewish humour in the concentration camps. It is neither a form of protest nor a form of fatalism. It demonstrates that the victims were critical of what happened around them, and by cracking jokes about it, diminished the authority of the oppressor vis-à-vis the victim (Barwick 2012: 172). For the victims, this type of humour functioned as a spiritual weapon to turn the situation upside down, and feel equal or even superior to their oppressor. "Resistance was expressed in the constant effort to maintain inner freedom while outwardly adapting" (Pawelczynska 1979: 127). 


\section{The functions of humour during the siege of Sarajevo}

The Bosnian war started right after the disintegration of Tito's Yugoslavia, after a referendum in April 1992 in which the multi-ethnic Republic of Bosnia and Herzegovina, inhabited by Bosniaks (Bosnian Muslims), Serbs and Croats, voted to secede from Yugoslavia. This was boycotted and challenged by the Bosnian Serb government and war between three different ethnic groups broke out. On the one hand, Bosniak forces fought the Serbs, who were mobilized by Slobodan Milošević and supported by the Yugoslav People's Army. On the other hand, war broke out between the Bosniaks and the Croats, who had first supported them. Propaganda, hate campaigns against 'the other', and ethnic cleansing featured in all the armies' strategies, but Serb forces carried out fully-fledged genocide against the Bosniak population, in order to establish a homogenous and pure Serbian state and society (Weitz 2003: 190). Before the war, when many ethnic and religious groups lived together under a repressive communist regime, jokes were characterized by regional and ethnic stereotypes. Bosnian humour was especially known for its self-mocking character; Bosnians themselves were often the butt of the joke (Vučetić 2004: 1). What happened to this humour during the war, especially in Sarajevo during the siege by Serbian forces from 1992 to 1996 ?

Much like victims of the Holocaust, for the inhabitants of Sarajevo too, every aspect of life changed. People had to adapt in order to survive the daily shelling, sniping, violence, and hunger. Some Bosnians escaped the new meanings of daily life by disconnecting psychologically or by fleeing. They were called prolupati, the Serbo-Croatian term for emotional numbness and irrationality that followed an excess of pain. For example, some people defiantly stood in open places during the siege as if nothing was going on, but they had a higher risk of being sniped. They might have escaped the circle of victimization and re-established some sort of normalcy, but the price was losing contact with their feelings, including the fear necessary for physical survival. In Bosnia they were called the zombies of the war (Maček 2009: 8).

Other people responded to these changes with a dark but strong sense of humour. People found pieces of normality, sanity, and hope in wartime art (Kurtović 2012: 212). As already mentioned, the arrival of an alternative "siege culture" came into existence, with film festivals and other cultural projects. This was a way of resisting the violent Serb attempts to destroy Bosnian culture (Sheftel 2011: 148), but also fulfilled the function of coping. During the siege, a group of Sarajevans launched a radio show, called the Surrealist Hit Parade. They cracked jokes about (and against) the Serbian President Slobodan Milošević and Serb-nationalist leader Radovan Karadžić, but also about daily life in Sarajevo. The authors justified their lampoonery as follows: "If someone is destroying your life, the worst thing you can do is just sit and let it happen. You have to find humour to be able to function during months of depression like those we have suffered here." (quoted in Sudetic 1993.) Jokes were a typical way of commenting upon situations of destruction and humiliation. People who survived the siege would say that physical survival was running away from the snipers and mortar shells on daily basis, cutting the trees from the parks for the firewood, getting fresh water, food, and medical supplies, while mental survival was telling jokes about such a situation. Moral boundaries about what is funny changed, morbid humour about the new reality of daily life came into being and became mainstream (Tumarkin 2005: 146).

In Bosnia, too, cohesion played a major role as humour also strengthened the need to find others to share a sense of belonging with. Maček claims that during the war in Bosnia acceptance into a group was conditional on one's capacity to laugh at oneself. Only then, a spirit of 
solidarity could emerge among those who shared the same predicament (Maček 2009: 10). In Bosnia, curfews were the first measures imposed by the Serbs when conquering a town. For the tens of thousands of Bosnians who went through the terror of the checkpoint system, jokes were meaningful: they exposed the absurdity and inhumane logic of the network of checkpoints set up by the Bosnian Serb authorities. One joke, as heard from a Bosnian source, goes:

A Bosnian man shows up at a checkpoint, half an hour before the evening curfew. "Where are you going?" asks the Serb soldier manning the checkpoint. "To Tito street", answers the Bosnian, whereupon the Serb aims his gun and shoots the man in the head. "What the hell are you doing?", asks the Serb commander, "he was still in time before the curfew!" The Serb soldier answers: "Yes, but I know where Tito street is, he wouldn't have made it in time."

Both the experience of checkpoints, and the cultural responses to them had the strong potential to advance group identity and cohesion. Having gone through checkpoints emerged as a defining identity marker of any survivor of the war.

Finally, a word about criticism. During the siege of Sarajevo, artistic and humorous responses were very much directed at the inhabitants, not only at the Serbs as the aggressors. The Sarajevans had to survive in dire circumstances: there was never enough food, always a continuous threat of sniping and shelling, and hardly any electricity or running water. Art was a way to turn the situation around, to take action, and not be dependent on the situation and the oppressor. By seeing themselves as artists, instead of victims, Sarajevans disempowered the oppressor. During the siege, the FAMA Foundation, an independent production company, introduced political entertainment and established several cultural projects with artists and intellectuals. According to the FAMA, this was a very natural response to the violent war: "In the situation of extreme danger, people need the creative force that the arts provide. (...) Every performance was a victory of civilian life over war" (Maček 2009: 55). There were concerts and theatre performances, most of them were during the day, because people were cut off from electricity most of the time. Many of these performances, concerts, and exhibitions featured antiwar messages. Larisa Kurtović estimated that this 'alternative culture' during the siege consisted of some 182 theatre productions, 170 exhibits, and 48 concerts (Kurtović 2012).

One of the projects of the FAMA was the Sarajevo Survival Guide, which was written by several artists in Sarajevo between April 1992 and April 1993 and published in 1994. (Sarajevo Survival Guide | Survival Forum.) The survival guide is a parody of a travel guide, taking visitors not to see touristic highlights, but giving them a tour through the city and instructing them on how to survive without transportation, hotels, taxis, telephones, food, shops, heating, water, information, and electricity. The book treats the daily, absurd reality for the victims, and although it is intended to be humorous, it is at once an accurate picture of real wartime life. The authors of the guidebook argue that the guide could assert the spirit of Bosnian people in the face of their annihilation and that it showed the city of Sarajevo "not as a victim but as a place of experiment, where wit could still achieve victory over terror." Humour was used as a "weapon" of the powerless, to acquire a sense of control in a situation that was actually controlled by a far superior enemy. The parody of the guide correspondents to the atmosphere of grim and sick jokes people already told each other. Ivana Maček argues that "joking was a significant form of resilience in Sarajevo. Not only could the most painful problems be expressed and shared 
through jokes, but their self-mocking perspective achieved a sense of control and distancing from everyday circumstances." (Maček 2009: 51.)

\section{The functions of humour for victims of the Syrian uprising and war}

Before the uprising in 2011, Syrians had undergone four decades of authoritarian rule under the regimes of Hafez al-Assad and his son Bashar. Political humour existed in this period, but most research suggests that this political humour was not necessarily overtly anti-regime. According to Lisa Wedeen, Syrians neither challenged power directly, nor did they uncritically accept the regime's version of reality. Humour was not a form of protest, but it was not merely a safety valve either. In authoritarian fashion, the Assad regime demobilized its citizens and discouraged civil society initiatives from engaging in art and culture. Political humour therefore only transformed the Syrian government's repression into a tolerable experience (Wedeen 1999: 87). The Syrian uprising in March 2011 sparked a novel burgeoning of political humour. The internet and social media sites such as Facebook, Twitter, YouTube, and blogs became the means of communication for the protesters. As protests were organized on the streets, art and political humour spread through these new media. The internet's importance was stressed in the following early joke from Egypt: "After his death, Hosni Mubarak met his predecessors Gamal Abdel Nasser and Anwar Sadat. 'Poison or gunfire?' they asked. 'Facebook', he replied” (Mersal 2011: 671).

The humour of the uprisings in Syria, which began in 2011, was a part of activism, because humour accompanied and was used in mass protests against the regime. However, jokes also became an important coping mechanism for people to deal with the hardships of the regime, the cruelty, violence, and death. By cracking jokes, people confronted their fears, sadness, and anger with the regime, making it an important coping device and a release of tension. A prominent Syrian satirist said that "humour was the only way I could deal with my anger" (quoted in Rundle 2012). Much like in Sarajevo and in the Nazi concentration camps, jokes were a way of coping with the changes of daily life. This Syrian joke highlights the widespread dearth of basic goods and services, like the availability of gas:

A man returns home with a live chicken for dinner... His wife tells him the family no longer has a knife to slaughter the bird, nor do they have gas to cook it with. Upon hearing the news, the chicken begins clucking: "Long live Bashar! Long live Bashar!"

(Chernin 2013.)

When the first winter came and made survival even more difficult, especially in besieged neighbourhoods and refugee camps, Syrians adapted and made jokes. For example, in an article about the hardships of winter, three Syrian rebels are posing and laughing with an armed snowman (al-Homsi 2013). This image seems absurd since Syrian people are actually freezing to death, but for the creators of the snow puppet it might be a way to cope with this. Something else that should be kept in mind is that the armed Syrian opposition lacks a lot of manpower in contrast to the government's forces. The snow puppet could therefore symbolize their need for extra manpower. 
As in the Jewish and the Bosnian cases, "the war in Syria is designed to kill hope, soul and moreover humanity" (Mrabet 2014). With so much violence directed at unarmed civilians, it may seem inevitable to become indifferent or succumb to hopelessness. However, dark and sarcastic humour uplifts the morale in the face of death and tragedy. From the very beginning of the uprising, the regime responded with brutal force, killing scores of unarmed demonstrators, spreading immense fear in Syrian society. But even the fear of death became the butt of jokes. The documentary \#chicagoGirl: The Social Network takes on a Dictator contains a scene in which two men are filmed before they take to the streets to protest. One young Syrian is lying on a couch watching TV, while a friend is taking pictures of him, saying: "I am totally going to upload this photo when you die". (Piscatella 2013.) The reference is to the tradition to upload to social media pictures of mostly non-armed people killed by the regime. As these are mostly serious portraits, the image of a man slouching on a sofa would not fit this tradition at all.

The city of Homs has seen some of the worst violence in the uprising. Under siege by the Syrian army, the Homsis are cut off from basic amenities such as electricity, water, food, sewage, and waste disposal. Movement inside Homs is extremely difficult because of the increasing number of checkpoints and snipers, who shoot randomly at people within a neighbourhood. The incessant sniping sparked a dark sense of humour in Homs. In one video clip, activists explain that anyone in Homs could be shot by a sniper (see 'Syrian activists joke, "We like playing with snipers"). In the background, one can see people peering into the distance, trying to get a look at the sniper, then sprinting across the street. At the end of the video, the activist says: "We like playing with snipers. Let me show you what happens when I throw a bag. Here it is." As soon as he tosses the bag of sand, sounds of shooting follow and the bag is pierced, followed by widespread laughter by the onlookers. In the documentary \#chicagoGirl, two men are running through the streets of Homs with their cameras, filming the explosions. When they are targeted by snipers, one of them jokes to the camera: "What a great morning jog! I do this every day." The absurdity of these jokes is that they contradict the bitter, mainstream attitude about snipers: Syrians are terrified of the random and sudden deaths the snipers mete out.

From the beginning of the Syrian uprising, social media proved to play a crucial role in organizing protests, spreading humour, and empowering the protesters. For the first time in decades, Syrians took to the streets to make their opinions known and to take action together. This newly constituted public space was through political and artistic initiatives. The uprising forged connections across class, gender, and age, and the common political cause against Assad created a strong solidarity. Before the regime's violence escalated considerably in the winter of 2011-2012 and the opposition's humour became bitterly dark, the protesters' humour was largely cohesive. The young men who led the demonstrations, chanting songs and slogans against the regime played an important symbolic role in the uprising as their novel, revolutionary humour bolstered cohesion among a wide spectrum of anti-Assad demonstrators.

The award-winning documentary Return to Homs is a good example of the shift in this tradition. The film shows how in 2011 demonstrations were organized in Homs, the selfproclaimed "capital of the revolution". In the repressed working-class neighbourhoods of Baba Amr and Khaldiye, the young charismatic activist Abdelbasset al-Sarout is seen standing on a podium, leading large demonstrations by singing and chanting with his characteristic guttural voice. Sarout's sense of humour transcended the classical Homsi tradition of humour, which was largely self-sarcastic and produced regional or urban identity. Sarout and his friends joke about living under siege, sniping, and bombardment - jokes that only make sense to Syrians who 
shared those violent experiences across Syria. In other words, in the slipstream of the violence, victim humour functioned as a major vehicle of solidarity and group identity. (Derki 2013.)

The critical role of Jewish and Bosnian humour is ambiguous, in that it served both defensive and offensive purposes. Humour is offensive, because it targets the Other, but it was mostly directed inwards rather than directed at the German or Serb oppressor directly, and therefore one could call it defensive as well. Syrian humour seems to be an expression of criticism, protest, and confrontation more unequivocally, because it is directed inwards and outwards. We argue that Syrian humour is inextricably connected to political activism, because humour was used in the mass demonstrations that aimed to overthrow Syrian president Bashar al-Assad. Thus, humour is very much connected to politics and power, more so than the other two cases. Whereas in the other two cases oral jokes and in the Bosnian case, printed media, were the prominent types of humour, in the Syrian case humour is expressed through cartoons, slogans, satirical shows, pictures, and videos as well as oral jokes.

Humour became the vehicle par excellence to delegitimize the Assad regime and deconstruct its symbols. One of the first uses of humour in the uprising were Ali Ferzat's cartoons. With the first stirrings of the uprising, Ferzat decided to target Bashar al-Assad directly with his cartoons, which was not possible before due to the dictatorship in which direct criticism of the Syrian leadership was not tolerated. It was the first time anyone had explicitly drawn the Syrian president since the Ba'ath party took over control in 1970 (Halasa, Omareen \& Mahfoud 2014: 168-172). Ferzat therefore directly undermined Assad's power, by depicting him as fleeing the country. His cartoons were carried by protesters in mass demonstrations. Furthermore, pictures of people holding caricatures of Assad became widespread. Due to the personality cult instilled by Hafez al-Assad, pictures of the president were once almost sacred to regime loyalists, but were now ridiculed on a large scale. According to Camps-Febrer, "[f]or Syrian people to break free of the state's grip the leader has to be exorcized; decrowned through ridicule by exaggerating his flaws and putting him in degrading positions" (Camps-Febrer 2012: 28). For example, Bashar's official picture can now be found in people's toilets, degrading his high and untouchable image, and in many caricatures Assad's floppy ears and long neck are the subject of ridicule.

The government retorted not only with violence but also with propaganda. A billboard campaign showing a raised hand said: "Whether progressive or conservative, I am with the law" or "Whether boy or girl I am with the law." Soon hereafter, parodies were circulating all around the internet, such as: "I am free", "I lost my shoes", or simply "I am with Syria". (Ratta 2011.) By using the same symbol (the raised hand), but changing its meaning, Syrians undermined the regime's narrative. The official narrative of the state depicts protesters as murderous terrorists, because Assad wants to convey a particular picture to the outside world that the regime is fighting off terrorists. The sarcastic banner "We're terrorists and trouble-makers. Don't you see our weapons?" clearly took a shot at Assad's propaganda, by joking that banners are their weapons, whereas they actually represent peaceful protest (al-Zubaidi 2012). This contradiction or incongruity makes the text funny to protesters of the regime. The regime also dehumanized the protesters by describing them as "germs" that should be eliminated. Syrians mocked this with the slogan "We are all germs" and presenting Assad as "Doctor Dettol", referring to a cleaning detergent. Insults by the regime are thus inverted into symbols of pride to create a collective identity. For a long time, the regime had largely controlled the world of political symbolism and dominated the meanings and interpretations of events. By using humour, opponents of the 
regime reversed the narrative and thus the power relations, reinforcing their own empowerment (Culture in Defiance 2012).

Another form of empowerment was the popular satirical series Top Goon: Diaries of a Little Dictator, created by a group of artists calling themselves Masasit Mati. This self-funded, simple finger puppet show of five-minute episodes covering two seasons makes fun of President Assad. According to Top Goon director Jameel, "[t]he idea was to break down the wall of fear" (quote in About Top Goon | Masasit Mati). The producers sought to strip down the personality cult surrounding Assad, depicting him not as a great dictator, but as a juvenile, often insane, puppet figure with the affectionate name "Beeshu". The show amplifies Assad's physical characteristics, giving Beeshu an even longer head, bigger nose, and floppier ears, and making his lisp more explicit. In the first episode of 23 November 2011, Beeshu is having trouble sleeping because he is having nightmares in which the regime is toppled. His right hand, Shabih (a thug who represents the Syrian armed militia, the Shabbiha), is trying to get him back to sleep by singing the morbid lullaby: "Go to sleep, I will kill all the people of Syria". Other episodes revolve around moral choices, coping with loss, torture, international passivity, and especially deconstructing regime propaganda. Top Goon thus empowers the revolutionaries morally and disempowers Assad visually by depicting him as an unthreatening baby. (Masasit Mati 2011.)

\section{Humour after victimization: changing traditions of self-deprecation}

What happened to the humour of victims after their victimization? We argue that dark humour among victims of genocide existed and could exist after their victimization, because most of its functions that have previously been discussed remained important for the victims after their victimization.

Several studies have looked at the way victims coped with their emotions after their victimization. Jacqueline Garrick introduced humour as a tool in individual and group therapy for Vietnam veterans (Garrick 2006: 170). She found that on the one hand, the exchange of humorous stories created a safe atmosphere in which the most painful memories and thoughts could be shared with greater ease. Humour also functioned as a release of tension when this became too great. Survivors often reported seeing themselves as having a sick sense of humour, which means they feel guilty for the things that they laugh at.

Interviews with Jewish survivors, stored at the Jewish Historical Museum in Amsterdam, demonstrate that some survivors feel shame and guilt for having survived and the more for having joked about the violence. For example Dave Furth, a child of Dutch Holocaust survivors, recalled that his family joked a lot after the war. He saw it as a way to push away any feelings, not coping with what had happened. (Furth.) Anna van Raalte mentions that, when talking about the period 1940-1942, she and her friends laughed a lot about the war. "Real Jewish humour", she calls it. But when the interviewer asks her if she can give an example of a joke, she answers: "No, no, because in our heart we knew it was not so funny." (van Raalte.) She feels as if she has to protect what she said before, it feels taboo. Norbert Buchsbaum said: "It sounds kind of crazy, but yes, we laughed a lot", and Maurice van de Pol also immediately defends himself when talking about humour: "We laughed a lot. It's unbelievable but we did. And the jokes were so sick." (Buchsbaum; van de Pol.) The fact that he calls the jokes "sick" might suggest that he feels guilty about it. At times, there is a contradiction between enjoying oneself while at the same time telling a gruesome story, typical of how survivors sometimes cope with their experiences. 
In this light, Garrick argues that therapists can help victims in understanding that humour is very often a vital part of their ability to cope with emotionally stressful and sometimes horrific events. Importantly, humour can also alleviate the survivor's guilt. Getting survivors to focus on their humorous memories can be a means of encouraging group cohesion and validation. Laughing together can ease the shame and loneliness they have attributed to their self-described "sick" sense of humour (Garrick 2006: 179-180). This suggests that humour after victimization fulfils largely the same functions that it does during victimization: coping and cohesion.

Whereas at first it was widely argued that the grim reality of the Holocaust could never be expressed through art, with time this slowly began to change. By now, there is a large body of Holocaust literature and art, and second- and third-generations of Holocaust survivors use humour profusely in their work (Kalmann 2009). Several children of Holocaust survivors use humour in books or comedy shows to describe their childhood, growing up with the legacy of the Holocaust.

There is one example of self-mockery, by joking around with the meaning of the loaded term "survivor". Larry David, a Jewish-American writer and comedian, jokes about the Holocaust in his comedy show Curb your Enthusiasm. David is giving a dinner party and the rabbi, who is invited, says he is bringing a "survivor" with him. Larry imagines that the rabbi meant a Holocaust survivor, invites his father's friend Solly, a Holocaust survivor, to make the rabbi's "survivor" friend feel more at ease. But it turns out that the rabbi has invited a contestant from the television show Survivor. During the awkward dinner, the two men get into an argument about who suffered the most. The dinner guests are far more focused on the handsome, young survivor and his stories than on the old Holocaust survivor. The episode subtly plays around with the loaded term "survivor", by suggesting it is arbitrary and has no fixed meaning. Moreover, by getting into a fight about who had the toughest time and who is the real survivor, the show also mocks the victim role of the Jewish people. (David 2004.)

When joking about the Holocaust, the joke's outcome depends highly on who the joker is. In general it is more accepted for Jewish people to joke about their history and the Holocaust. It is not a coincidence that so many American comedians are Jewish; the 'victims' in this case, can mock themselves and the perpetrators. Both Jewish and Bosnian humour is characterized by the mockery of their own victimization. For the perpetrators, or at least, their grandchildren, it is much more taboo to joke about their own perpetrator role and especially about the victims. When a German jokes about Jews, the risk will always remain that it is perceived as anti-Semitic. Jokes that ridicule Hitler and the Nazis are more accepted, because they delegitimize or criticize the Nazis, but they have to be careful as well not to be too light about it, for this could be interpreted as trivializing what the Nazis did. Oliver Polak is a Jewish, German comedian, who tries to tackle loaded subjects such as the Holocaust in his comedy shows. He argues that by making fun of being Jewish, he gives his German audience a chance to laugh at his Holocaust jokes instead of showing their guilt for what their Nazi ancestors had done (Kitty 2014).

According to Channa Kalmann, "[i]t is not appropriate to laugh or joke about the Holocaust itself and it never will be. There is still a moral boundary about what is acceptable and what is not" (Kalmann 2013: 42). Humour is still associated with the trivialization of what happened, denial or just not taking it seriously. According to Kalmann, humour is allowed when the intention of the teller is clear, when he is not just making cheap, "distasteful" jokes to make a joke, but in order to cope with the past or prevent oblivion. In general, people are so afraid of being called a racist or anti-Semite; they enforce strict moral codes and judge jokes very easily. There is an ethical conflict between emotions (laughing) and ratio (moral codes). However, the 
funniest jokes are always the ones that balance on these moral boundaries and a lot of jokes have a clear target. However, this does not automatically mean that the joke teller or the joke receiver is aggressive or negative towards the butt of the joke. Jokes and laughter are ambivalent and can never be reduced to having only one meaning (Kuipers 2001: 29). If jokes cause bad behaviour, such as racism, or are a sign of bad behaviour, then this would cause a moral objection to the jokes. (Cohen 1999: 80.) But if this would prove not to be the case, people would probably still be afraid someone would judge the joke as disturbing.

It should not only be kept in mind that in the current digital media age, jokes can easily lead to controversy, because different audiences can have different interpretations of the joke. Consequences of jokes resonate further and the audience no longer observes the limits of a comedy club. For example, dark jokes among genocide scholars can only be successful when the group consists of mainly genocide scholars with the same background, who understand the joke and perhaps all laugh because they need the same release of tension in their difficult research field. These private jokes would lose their sense of humour and appropriateness when they would be published in a public newspaper.

Contrary to the Jewish victimization, the Bosnian victimization was far more recent. How did the Bosnian humour change after the war? Directly after the war, Bosnian humour was distinctively characterized by aggressive jokes in which the enemies, Serbs and Croats, became the butt of the joke (Vučetić 2004: 13). The war thus broke a taboo in engendering ethnic jokes with unmistakable hostility. For example:

A Bosnian, a Serb and a Croat got drunk in Saudi Arabia. Some locals report them to the police, so they got arrested. "Because you are foreigners and didn't know the laws, you will not be severely punished," proclaims a Saudi judge. "Each one of you will get a beating consisting of 50 lashes on the back, but each will also be granted one wish with respect to the beating - but the Bosnian gets two." The Croat says: "Before you start, I'd like you to tie a pillow to my back." After five lashes, the pillow hits the ground and the lashes continue. The Serb says: "Before you start, I'd like you to tie two pillows to my back." After ten lashes, both pillows fall off and the lashes continue. The Bosnian says: "First, I'd like 100 hits instead of 50." Saudis were quiet a little, but decided to wait for his second wish. "Second," the Bosnian says, "please tie the Serb tightly to my back."

(See Kiley 2012.)

The war also changed the traditional Mujo and Suljo jokes. The stereotypically naïve though sometimes shrewd Bosnian duo remain the same, but the jokes deal with the post-war situation now. The following joke mocks the many casualties of war:

Mujo is driving through Sarajevo in his new Mercedes, with his arm leaning on his open window, when suddenly his friend Suljo stops him and says: 'Mujo, there is no need to flaunt like that, today almost everybody has a Mercedes in Sarajevo'. Mujo replies: 'Yes, but not everybody has an arm.'

(Beyen 2006: 152.)

According to Anna Sheftel, there is a tendency among Bosnians to mock their own victimhood and their inferior role during the war. According to popular belief, the Bosnians were very passive and realized far too late that the war was serious and targeted them. This passive 
role in some cases led to feelings of survivor guilt, but rather than glorifying Bosnians' victimhood in the war, post-war humour critiques it. Bosnians' self-aware use of humour serves to make present-day Bosnians regain their dignity and intelligence. Laughter at oneself serves both as a critique as well as release, exploring feelings of shame and foolishness about their role in the war. They may have been considered to be passive during the war, but the post-conflict situation allows them to counteract that reputation through humorous self-critique (Sheftel 2011: 153).

This is expressed best in the movie No Man's Land that treats the war in a darkly comical way. The film depicts three soldiers, one Serb and two Bosnian Muslims, who are trapped between the two armies' front lines (Sheftel 2011: 151). One example of self-mockery is when the two Bosnian soldiers comment on a radio news item about Rwanda, as one soldier says to the other: "Did you see, such a mess in Rwanda!" (Tanović 2001.) The fact that they comment on the bloody situation in Rwanda, while they are in a serious conflict themselves, is paradoxical. By using humour, No Man's Land deals with the traumatic past. The dark humour serves as a relief mechanism for Bosnians who are still coping with their past. Director Danis Tanović stated that using humour was very natural to him:

We are the only region to have a good sense of humour, Bosnians. I think it's a way of surviving. Humour gives you a distance. So we laughed a lot during the war. It was our secret weapon. So I thought why not treat a subject that was serious with a good sense of humour. It eases up certain things.

(Quoted in Fischer 2001.)

Another interesting development in the Balkans is stand-up comedy, which is a new, but popular phenomenon. The documentary The Happy Sad Route (And a Comedian) includes interviews with Balkan comedians about their lives and work (Hakeboom 2013). Aleksander Perisić, a Serbian comedian, explains that in his experience, telling jokes about the war makes the audience feel relieved. He confesses that he feels a bit fed up of these jokes, but the fact that especially those jokes are so popular strongly suggests that the audience benefits from them emotionally. The Bosnian comedian Miranda Loncar uses self-mockery, especially about the victim role of Bosnia: "Miss Bosnia never stood a chance. All the other contestants were promoting world peace, but she could only wish peace for Bosnia." Stand-up comedy and films such as No Man's Land might be the beginning of a tradition of a new cultural approach to and treatment of the recent past.

At the time of writing, the conflict in Syria has entered its third year and we cannot draw definitive conclusions about the functions of humour after victimization. However, we can look at the changes of humour as the conflict becomes ever more violent, and hypothesize that humour most likely will not cease to exist but will only become darker, potentially reaching cynicism. In other words, the intensity of the violence is commensurate with the levels of coping that are needed for the victims. For example, artists from the city of Kafranbel, who supported the uprising from the beginning and became famous for their humorous banners, continue this peaceful form of protest. But their messages and humour have become uncharacteristically darker. After the regime attacked the people with chemical weapons, they responded with the banner: "World! You will try to save us when Assad will have used his nuclear weapons. Isn't it?" 
Humour changes when people adapt and become accustomed to the violence, as their moral boundaries shift and they laugh at things they would not have laughed at before. In a video from November 2013 from the devastated suburbs of Damascus, activists interviewed children about life under bombardment. During this interview, bombs fall on a nearby street, and after taking cover, the children laugh off the strike. The children are so brutalized by the daily violence that they respond with cynical laughter. (The Revolting Syrian-بـ شار دا إرحل يـ لا.) The revolutionary humour on social media is turning more cynical as well. In June 2014, Syria held presidential elections. Activists have started a social media campaign to mock Assad's decision to hold elections in the midst of a very bloody conflict, with slogans such as: "Assad: putting 'laughter' in 'manslaughter' since 2011." (Coevert 2014).

Humour clearly is also a survival instinct. Even after three years of relentless mass violence against civilians, Syrians still take to the streets to protest, and humour still operates as a crucial resilience mechanism, motivating people and boosting morale. Cracking jokes when living circumstances are dire is also a way of keeping human dignity. As mentioned in the previous section, Viktor Frankl argued that the human will to live is extremely important, and humour is one of the vital ingredients of mental perseverance. This inner, mental struggle for human identity also seems to be ongoing in Syria. The quote by a Holocaust survivor: "We could still laugh at things", could just as easily been said by a Syrian (Ostrower 2000).

\section{Conclusion}

This article has explored the types and functions of humorous responses to victimization in the three cases of the Holocaust, Bosnia, and Syria. Despite the clear differences between the three cases, we found that the victims' responses are remarkably similar. The means of humour range from slogans to theatre, cabaret, and stand-up comedy, and includes self-mockery, absurd jokes and cynicism about the perpetrators. In all three cases, some types of humour were more prominent that others. In the case of the Jewish victims we focused mostly on oral jokes. In the Bosnian case we focused on both oral jokes and printed media, and in the most recent case, Syria, social media greatly influenced the type of humour and enhanced the spread of jokes. Despite the different appearances and forms of humour in these three cases, its functions appear to be strikingly similar.

The functions of victims' humour are threefold. Throughout the periods of genocide, all three groups of victims had to adapt to new, horrible situations in order to survive. If many jokes were bitter and even cynical, it was because above all, they arose from pain. One way of coping with the gruesome reality was the use of humour as a defence and escape mechanism. In order to cope, one needed to adapt; in order to adapt, one needed to joke. Overcoming fatalism was essential to survival. Laughing could mean that they have a sense of control over the violent and uncontrollable situation, it could distract them, manage their emotions, or ward off their suffocating fear. Cohesion is a second main function of victim humour. In all three cases, the jokes were hard to tell outside of Sarajevo, Syria, or the ghettos and camps. Not only because the humour was macabre, but also because only those who were victimized would understand them. From this perspective, dark humour was an "experiential deformation" peculiar to the victims. In the words of Maček, "people who did not have the same sort of experience, who judged situations by peacetime standards, had no way to appreciate the jokes" (Maček 2009: 52).

Third and finally, humour can also be a form of criticism - in the Syrian case, humour is even a form of revolutionary activism. It is part of a powerful strategy in directly opposing the 
perpetrating regimes, because it challenges the official narrative of these regimes, by mocking, undermining and delegitimizing them. Humour can also have a more nuanced critical function, and both the Jewish and Bosnian genres of humour are self-deprecating. By joking about the oppressor and themselves, they can oppose their forced victimization, by reversing the roles between perpetrators and victims. In all three cases, the arrival of an "alternative culture" and humorous approaches were a way of resisting the violent attempt to destroy Bosnian, Syrian, and Jewish culture. Indeed, humour during the Syrian uprising helps people feel superior over the Assad regime and enhances their self-esteem. Although humour and creative resistance might not be able to topple the regime, the regime has been toppled in the minds of most citizens and the culture of self-censorship has been breached like never before. Syrian satire underlines and strengthens the actual protests and resistance movement.

There is a popular tendency to consider victims of genocide to be passive, and survivors as victimized for the rest of their life. However, the fact that people joked about the hardships, their oppressors and themselves, demonstrates that victims are not that passive at all. They were fundamentally aware of what was going on, commented on it with jokes and coped with it through humour. This testifies to the resilience of the survivors. After their victimization, humour could still function as a coping, cohesive and critical mechanism. Cracking jokes when living circumstances are dire was a way of maintaining human dignity. All three cases demonstrate that when victims are able to laugh at oneself or at the Other, even in the most inhumane circumstances, a modicum of humanity and dignity can be maintained.

\section{References}

'About Top Goon | Masasit Mati'. Available online: http://masasitmati.org/wp/about-the-serietop-goon/ [Accessed on 02 April 2014].

al-Homsi, Yazan (2013). 'In Besieged Homs, Residents Fear Disastrous Third Winter', Syria Deeply, 15 November 2013. Available online: http://beta.syriadeeply.org/2013/11/besiegedhoms-residents-fear-disastrous-winter/\#.UqjTA8s1jqA [Accessed on 02 April 2014].

al-Zubaidi, Layla (2012). 'Syria's creative resistance', Jadaliyya, 8 June 2012. Available online: http://www.jadaliyya.com/pages/index/5920/syrias-creative-resistance [Accessed on 02 February 2014].

Alvarez, A. (2010). Genocidal Crimes. London: Routledge.

Barwick, N. (2012). 'Looking on the bright side of life: Some thoughts on developmental and defensive uses of humour', Psychodynamic Practice: Individuals, Groups and Organizations 2, pp. 63-179.

Beyen, M. (2006). Humor met een verleden. Leuven: Universitaire pers Leuven.

Bloxham, D. \& Moses, D. (eds.) (2010). Oxford Handbook on Genocide Studies. Oxford: Oxford University Press.

Buchsbaum, Norbert. Interview with Norbert Buchsbaum, interview code 08912. Available at: Visual History Archive. USC Shoah Foundation. [Accessed at the Jewish Historical Museum Amsterdam on 3 February 2013].

Camps-Febrer, B. (2012). 'Political humour as a confrontational tool against the Syrian regime: a study case Syria, 15th March 2011 - 15th May 2012', International Catalan Institute for Peace, Working Paper No. 2012/8. Available online: http://dx.doi.org/10.2139/ssrn.2205200 [Accessed on 13 January 2015]. 
Chernin, Michael (2013). 'Why So Syrious? Black Humor Amid Horror in Syria', Brown Political Review, 11 April 2013. Available online: http://www.brownpoliticalreview.org/2013/04/why-so-syrious-black-humor-amid-horror-insyria/ [Accessed on 2 April 2014].

Coevert, A. (2014). 'Chemicaliën voor een zonnige toekomst: Assad krijgt campagnehulp', NRC Handelsblad, 24 April 2014.

Cohen, E. (1959). Het Duitse Concentratiekamp: Een medische en psychologische studie. Amsterdam: H.J. Paris.

Cohen, T. (1999). Jokes: Philosophical Thoughts on Joking Matters. Chicago: The University of Chicago Press.

Cohen, T. (2001). 'Humour', in Gaut B. \& McIver Lopes D. (eds.), The Routledge Companion to Aesthetics. London: Routledge, pp. 375-381.

Culture in Defiance: Continuing Traditions of Satire, Art, and the Struggle for Freedom in Syria. Prince Claus Fund Gallery exhibition, Amsterdam, 4 June 2012 - 23 November 2012.

David, Larry (2004). Curb your Enthusiasm, episode 9, season 4 'The Survivor', 7 March 2004. Available online: http://www.youtube.com/watch?v=In2XfN3hIi4 [Accessed on 02 April 2014].

Derki, Talal (2013). Return to Homs. Directed by Talal Derki. Proaction Film.

Fischer, Paul (2001). 'Danis Tanovic: War As Satire', interview by Paul Fischer in Los Angeles, 11 December 2001. Available online: http://www.filmmonthly.com/Profiles/Articles/DTanovic/DTanovic.html [Accessed on 02 April 2014].

Frankl, V. (1992). Man's Search for Meaning: An Introduction to Logotherapy. Massachusetts: Beacon Press.

Furth, Dave. Interview with Dave Furth, interview code 06161. Available at: Visual History Archive. USC Shoah Foundation, accessed at the Jewish Historical Museum Amsterdam on 3 February 2013.

Garrick, J. (2006), 'The humour of trauma survivors: It's application in a therapeutic milieu', Journal of Aggression, Maltreatment and Trauma 12, pp. 169-182.

Gerlach, Ch. (2010). Extremely Violent Societies: Mass Violence in the Twentieth-Century World. Cambridge: Cambridge University Press.

Hakeboom, Linda (2013). The Happy Sad Route (And a Comedian). Directed by Linda Hakeboom. Het Station.

Halasa, M. \& Omareen, Z. \& Mahfoud, N. (2014). Syria Speaks: Art and Cultures from the Frontline. London: Saqi Books.

Herzog, R. (2012). Dead Funny: Telling Jokes in Hitler's Germany. Brooklyn NY: Melville House Books.

Hill, J. (2012). 'The bold comedians of Syria strike back', The Global Mail, 11 July 2012.

Janoff-Bulman, R. (1985). 'The aftermath of victimization: Rebuilding shattered assumptions', in Figley, Ch. (ed.), Trauma and its Wake, Volume 1: The Study and Treatment of Posttraumatic Stress Disorder. New York: Brunner/Mazel, pp. 15-35.

Jones, P. (2007). Aftershock: Confronting Trauma in a Violent World: A Guide for Activists and Their Allies. New York: Lantern Books.

Kalmann, Ch. (2009). Grimlachen na Auschwitz: Humor in de internationale Holocaustliteratuur. Soesterberg: Aspekt B.V. 
Kalmann, Ch. (2013). Mijn god waarom hebt gij ons niet verlaten: Humor in de internationale holocaust literatuur. Soesterberg: Aspekt B.V.

Keltner, D. \& Bonnano G. (1997). 'A study of laughter and dissociation: Distinct correlates of laughter and smiling during bereavement', Journal of Personality and Social Psychology 4, pp. 687-702.

Kiley, Brendan (2012). 'I wish you to see your own house on CNN: 15 Jokes from the Siege of Sarajevo, The Stranger, 5 April 2012. Available online: http://slog.thestranger.com/slog/archives/2012/04/05/jokes-from-the-siege-of-sarajevo [Accessed on 02 April 2014].

Kitty, D. (2014). 'Oliver Polak: Germany's only living Jewish comedian', Heeb Magazine, 18 August 2014.

Kramer, A. (2007). Dynamic of Destruction: Culture and Mass Killing in the First World War. Oxford: Oxford University Press.

Kuipers, G. (2001). Goede humor, slechte smaak: een sociologie van de mop. University of Amsterdam: Faculty of Social and Behavioural Sciences PhD thesis.

Kuipers, G. (2008). 'The sociology of humour', in V. Raskin (ed.), The Primer of Humor Research. Berlin: de Gruyter, pp. 361-398.

Kurtović, L. (2012). "The paradoxes of wartime "freedom": Alternative culture during the Siege of Sarajevo', in Bilic, O. \& Janovic, V. (eds.), Resisting the Evil: (Post-)Yugoslav Anti-war Contention. Baden-Baden: Nomos, pp. 197-224.

Lefcourt, H. (2001). Humour: The Psychology of Living Buoyantly. New York: Kluwer.

Lipman, St. (1993). Laughter in Hell: The Use of Humour During the Holocaust. Northvale, New Jersey, London: Jason Aronson.

Lorey, D. E. \& Beezley, W. H. (2002). Genocide, Collective Violence, and Popular Memory: The Politics of Remembrance in the Twentieth Century. Wilmington: SR Books.

Maček, I. (2009). Sarajevo under Siege: Anthropology in Wartime. Philadelphia: University of Pennsylvania Press.

Masasit Mati (2011). Top Goon, season 1, episode 1 'Beeshu's nightmares', 23 November 2011. Available online: http://www.youtube.com/watch?v=W5RifYxWr-4 [Accessed on 30 December 2013].

Mersal, I. (2011). 'Revolutionary humour', Globalizations 5, pp. 669-674.

Moffie, Janny. Interview with Janny Moffie, interview code 04538. Available at: Visual History Archive. USC Shoah Foundation. [Accessed at the Jewish Historical Museum Amsterdam on 3 February 2013].

Morreall, J. (2001). 'Humour in the Holocaust: Its critical, cohesive, and coping functions', in Sachs Littell, M. (ed.), Annual Scholars' Conference on the Holocaust and the Churches, 1990-2000. Vista-Intermedia. [CD-ROM].

Mosse, G. L. (1990). Fallen Soldiers: Reshaping the Memory of the World Wars. Oxford: Oxford University Press.

Mrabet, Ayla (2014). 'Photography: Behind Syria's War', Free Arabs, 17 March 2014. Available online: http://freearabs.com/index.php/photo-gallery-page-art/jb-span-photography-jb-spanbehind-syria-s-war\#!20 [Accessed on 02 April 2014].

Obrdlik, A. (1942) 'Gallows humour: A sociological phenomenon', American Journal of Sociology 5, pp. 709-716.

Ostrower, Ch. (2000). 'Humour as a defense mechanism in the Holocaust'. Tel-Aviv University $\mathrm{PhD}$ thesis. 
Pawelczynska, A. (1979). Values and Violence in Auschwitz: A Sociological Analysis. Berkeley: University of California Press.

Piscatella, Joe (2013). \#chicagoGirl: The Social Network takes on a dictator. Directed by Joe Piscatella. Revolutio LLC.

Rapaport, L. (2006). 'Laughter and heartache: The functions of humour in Holocaust tragedy', in Petropoulos, J. \& Roth, J. K. (eds.), Gray Zones: Ambiguity and Compromise in the Holocaust and Its Aftermath. New York: Berghahn, pp. 252-269.

Ratta, Donatella Della (2011). 'Irony, satire and humour in the battle for Syria', Muftah, 31 February 2011. Available online: http://muftah.org/irony-satire-and-humour-in-the-battle-forsyria/ [Accessed on 02 April 2014].

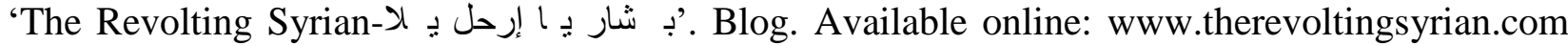
[Accessed on 02 April 2014].

Roskies, D. \& Diamant, N. (2012). Holocaust Literature: A History and Guide. Waltham, Massachusetts: Brandeis University Press.

Rundle, M. (2012). 'Syrian satire amid the bloodshed: what makes Syrians laugh?', Huffington Post, 31 March 2012. Available online: http://www.huffingtonpost.co.uk/2012/03/23/syriansatire-amid-the-bloodshed_n_1375491.html [Accessed on 14 September 2015].

'Sarajevo Survival Guide | Survival Forum'. 'Excepts from Sarajevo Survival Guide'. Available online: http://www.survivalmonkey.com/threads/sarajevo-survival-guide.19312/ [Accessed on 2 April 2014].

Sheftel, A. (2011). 'Monument to the international community: From the grateful citizens of Sarajevo: Dark humour as counter-memory in post-conflict Bosnia-Herzegovina', Memory Studies 2, pp. 1-20.

Sofsky, W. (2005). Traktat über die Gewalt. Frankfurt am Main: Fischer.

Spargo, C. \& Ehrenreich, R. (eds.) (2000). After Representation?: The Holocaust, Literature, and Culture. New Brunswick: Rutgers University Press.

Sudetic, Chuck (1993). 'Sarajevo Journal; This Can't Be Bosnia, There's Too Much Laughing', New York Times, 6 July 1993. Available online: http://www.nytimes.com/1993/07/06/world/sarajevo-journal-this-can-t-be-bosnia-there-s-toomuch-laughing.html [Accessed on 14 September 2015].

'Syrian activists joke, "We like playing with snipers", Los Angeles Times, 28 February 2013. Available online: http://latimesblogs.latimes.com/world_now/2012/02/syrian-activists-jokewe-like-playing-with-snipers-video.html [Accessed on 14 September 2015].

Tanović, Danis (2001). No Man's Land. Directed by Danis Tanović. Noé Productions, Fabrica Cinema, Man's Films, Judy Counihan Films, Studio MAJ-Casablanca.

Tangherlini, T. (2000). 'Heroes and lies: Storytelling tactics among paramedics', Folklore 1, pp. $43-66$.

Tels-de Jong, Leontine. Interview with Leontine Tels-de Jong, interview code 16753. Available at: Visual History Archive. USC Shoah Foundation. [Accessed at the Jewish Historical Museum Amsterdam on 3 February 2013].

Thurston, R. (1991). 'Social dimensions of Stalinist rule: Humour and terror in the USSR, 193541', Journal of Social History 24 (3), pp. 541-62.

Tsakona, V. \& Popa, D. E. (eds.) (2011). Studies in Political Humour: In Between Political Critique and Public Entertainment. Amsterdam: John Benjamins.

Tumarkin, M. (2005). Traumascapes: The Power and Fate of Places Transformed by Tragedy. Melbourne: Melbourne University Publishing. 
United Nations (UN). Statement by Mr. Adama Dieng, United Nations Special Adviser on the Prevention of Genocide, on the situation in Syria, 8 July 2013.

United States Holocaust Memorial Museum (USHMM), Center for the Prevention of Genocide, list of countries at risk. Available online: http://www.ushmm.org/confrontgenocide/cases/syria [Accessed on 3 February 2014].

van de Pol, Maurice. Interview with Maurice van de Pol, interview code 22962. Available at: Visual History Archive. USC Shoah Foundation. [Accessed at the Jewish Historical Museum Amsterdam on 3 February 2013].

van Raalte, Anne. Interview with Anna van Raalte, interview code 21298. Available at: Visual History Archive. USC Shoah Foundation. [Accessed at the Jewish Historical Museum Amsterdam on 3 February 2013].

Vučetić, S. (2004). 'Identity is a joking matter: Intergroup humour in Bosnia', Spaces of Identity: An Interdisciplinary Journal 2, pp. 1-28.

Wedeen, L. (1999). Ambiguities of Domination: Politics, Rhetoric and Symbols in Contemporary Syria. Chicago: The University of Chicago Press.

Weitz, E. (2003). A Century of Genocide: Utopias of Race and Nation. Princeton: Princeton University Press.

Ziv, A. \& Zajdman, A. (eds.) (1993). Semites and Stereotypes: Characteristics of Jewish Humour. Westport CT: Greenwood.

Ziv, A. (2010). 'The social function of humour in interpersonal relationships', Society 47 (1), pp. $11-18$. 